
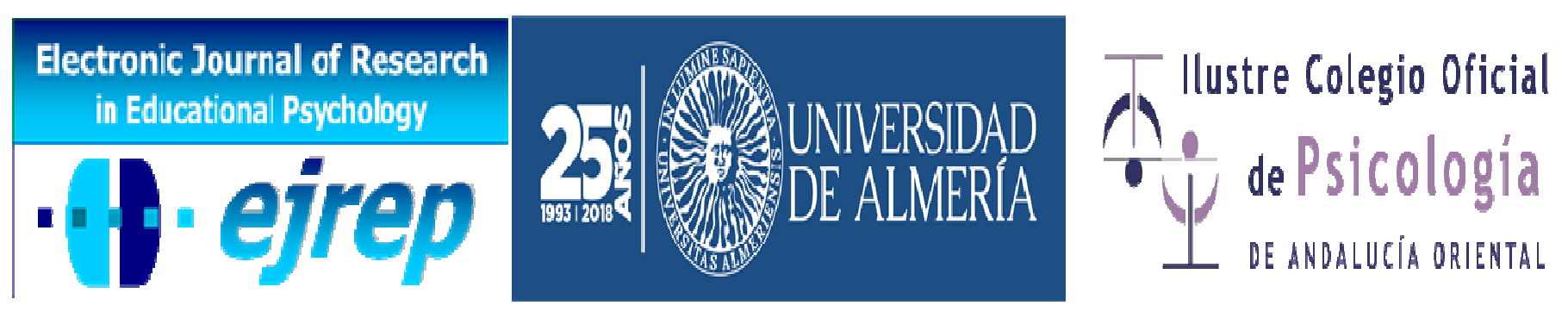

\title{
Development of the Exam Anxiety Scale for Parents: A Validity and Reliability Study
}

\author{
Kemal Baytemir ${ }^{1}$, Tahsin İlhan ${ }^{2}$
}

\footnotetext{
${ }^{1}$ Department of Guidance and Counselling, Amasya Üniversitesi, Amasya

${ }^{2}$ Department of Guidance and Counseling, Gaziosmanpaşa Üniversitesi, Tokat
}

\section{Turkey}

Correspondence: Kemal Baytemir. Amasya Üniversitesi, Eğitim Fakültesi, 05100, Amasya. Turkey. E-mail: kemalbaytemir@hotmail.com

(C) University of Almería and Ilustre Colegio Oficial de la Psicología de Andalucía Oriental (Spain) 


\begin{abstract}
Introduction. The aim of this study is to develop a measurement instrument for measuring the exam anxiety experienced by the parents regarding their children's exams.

Method. The data were collected from two different study groups. While the first group consists of 299 parents, 169 female and 130 male, the second group consists of 200 parents, 108 female and 92 male. Exploratory Factor Analysis (EFA) was conducted to examine the factor structure of the scale and Confirmatory Factor Analysis (CFA) was conducted to confirm the obtained structure. Additionally, criterion validity was investigated by using the state-trait anxiety inventory.
\end{abstract}

Results. The two-dimensional structure obtained through EFA was named as worry and physiological dimensions. In order to confirm this two-dimensional structure, CFA was conducted and the results showed that the sufficient model fit indices were gathered. For the criterion validity, positive medium correlations were found with the state-trait anxiety inventory. As for the reliability, the Cronbach's Alpha values computed for both the first and second study groups ranged from .88 to .93 for the sub-dimensions and the overall scale.

Discussion andr Conclusion. In light of the above mentioned results, it was concluded that the developed two-factor model is useful for measuring the exam anxiety of parents.

Keywords: Exam Anxiety, Parent Exam Anxiety, Scale development, Turkey. 


\section{Resumen}

Introducción. En esta investigación, el objetivo fue desarrollar una herramienta de medición para medir la ansiedad de los padres sobre los exámenes de sus hijos.

Método. Para este propósito, los datos se obtuvieron de dos grupos de estudio diferentes. El primer grupo de estudio consistió en 299 padres, de los cuales 169 eran mujeres y 130 eran hombres, mientras que el segundo grupo de estudio consistía en 200 padres, de los cuales 108 eran mujeres y 92 eran hombres. El análisis factorial exploratorio (AFE) se utilizó para determinar la estructura factorial inicial de la escala y se utilizó el análisis factorial confirmatorio (AFC) para confirmar el resultado. Además, las escalas de ansiedad de estado y rasgo se usaron para la validez de criterio.

Resultados. La estructura bidimensional obtenida a través de AFE fue nombrada como preocupación y dimensiones fisiológicas. Se obtuvieron valores de cumplimiento adecuados en el estudio AFC para confirmar esta estructura bidimensional. En el estudio de validez de criterio, hubo correlaciones moderadamente positivas entre las escalas de ansiedad estado-rasgo y la escala de ansiedad parental. Se encontró que los valores alfa de Cronbach calculados para la confiabilidad tanto en el primer como en el segundo grupo de estudio variaron entre .88 y .93 para todas las escalas y subescalas.

Discusión o Conclusión: Con base en estos hallazgos, se concluyó que la escala fue útil para medir la ansiedad de los padres que percibieron por sus hijos.

Palabras Clave: Ansiedad de prueba, ansiedad de prueba parental, el desarrollo de la escala, Turquía 


\section{Introduction}

Besides the regular oral and written exams to evaluate students' learning acquisitions along their school life, millions of students and individuals need to take central exams in varios periods of their lives in Turkey. According to the data regarding the central exams applied in Turkey, over two million candidates took the university exam (Student Selection and Placement Centre [SSPC], 2016a); over two and half million candidates took the exam for the selection of public staff among the students having associate and bachelor degree (SSPC, 2016b), over one million students took the high school entrance exam (Turkish Ministry of National Education [TMNE], 2016). These exams play important role in determining academic career of individuals. The exams used for the evaluation of students' academic success, which is influential for their educational future, increase their exam anxiety and accordingly intensified anxiety has adversely impact on their academic career (Von Der Embse, Barterian \& Segool, 2013). While the exam anxiety remains as a notable educational issue (Wigfield \& Eccles, 1989), it is experienced in various cultures (Seipp \& Schwarzer, 1996) and affects students' lives as a common problem (Ergene, 2003; McDonald, 2001). Therefore, it has become more important to understand role of exams influencing student success.

Anxiety is rather disturbing feeling which makes adaptation and lives of individuals difficult. It is a process that intervenes in the adaptation and organization of one's behavior (Sanz de acedo \& Sanz de acedo, 2012). On the other hand, exam anxiety is multidimensional structure including cognitive, psycho-social, physiological, behavioral reactions in face of being evaluated (Hong, 1998). Exam anxiety is considered one of the barriers before individuals' academic successes. Especially, students with exam anxiety have lower anxiety thresholds when they feel that they are evaluated for success. Thus, students perceive examinations as a threat, their self-efficiacy feeling decrease, they think they are going to fail; and they exhibit more intense emotional reactions (Ergene, 2003). Individuals who do not experience negative feelings during examination outperform the ones who have negative feelings (Fincham, Hokoda \& Sanders, 1989). Previous research have consistently reported that exam anxiety has negative effect on individuals' academic performance (Ergene, 2011; Koçkar, Kılıç \& Şener, 2002; McDonald, 2001; Morris \& Liebert, 1970; Steinmayr, Crede, McElvany \& Wirthwein, 2016). Individuals with high exam anxiety feel under threat when they are being evaluated; and negative assessment against them easily distracts them. Thus, 
they experience difficulty in reading exam questions accurately and in concentration of thoughts (Öner, 1990).

According to the studies in the relevant literature, it could be seen that irrational beliefs have significant role in explanation of exam anxiety (Güler \& Çakır, 2013); as the exam anxiety increases, submissive behaviors increase and perceived social support perception decreases (Gençdoğan, 2006); negative perfectionism and performance achivement goal oriantation has significant effect on exam anxiety (Eum \& Rice, 2011); students with external locus of control tend to be have higher exam anxiety (Başal, 1997); academic success, perfectionism and social support from peer and teacher are predictor of exam anxiety (Yildırım, Gençtanırım, Yalçın \& Baydan, 2008); decision styles (e.g. panic, avoiding responsibility, etc.) are predictors of exam anxiety (Bacanlı \& Sürücü, 2006); students who do not have regular studying habit have higher exam anxiety (Şahin, Günay \& Batı, 2006); and psychological resilience and social support are also negatively correlated with exam anxiety (Park \& Park, 2010).

Besides the number of personal factors influential on exam anxiety, attitude of people around students has effective on exam anxiety (Koruklu, Öner \& Oktaylar, 2006). A number of studies have shown that attitudes of parents are significantly correlated with students' exam anxiety (Çakmak \& Hevedanlı 2005; Duman, 2008; Güler \& Çakır, 2013; Hanımoğlu \& İnanç, 2011). On the exam anxiety, high success expectations of parents, their critical approach to exam scores, and excessive orientation of students on evaluations of their parents may result that students to feel over-pressure and under-performance (Çapulcuoğlu \& Gündüz, 2013; Hill \& Wigfield, 1984). Prominent researchers of psychoanalytic theory, such as Horney and Sullivan address childhood experiences and family communication dynamic in development of anxiety (Burger, 2006). In various studies (Adams \& Sarason; 1963; Alisinanoğlu \& Ulutaş, 2003; Whaley, Pinto \& Sigman, 1999), it was found that mother's anxiety is highly correlated with children's anxiety. Besides personality traits and emotional characteristics of persons, anxiety is also related with maternal interaction and childhood period surrounding. Family-child interaction not only affects anxiety arise in child; but also school performance (Peleg-Popko, 2002). Finally, raising environment and family of children could be effective in development anxiety. Therefore, it is important to realize role of family an intimate social setting of children in development of exam anxiety, one of anxiety types. 
While the preliminary studies on measurement of exam anxiety were viewing anxiety as a one dimensional structure, subsequent studies considered this as multi-dimensional (Stöber, 2004). Liebert and Morris (1967) made significant distinction about structure of exam anxiety classified it into two separate dimensions. Worry, one of these dimensions, is taken as cognitive section of exam anxiety and refers opinions of individual about exam performance while emotionality dimension, the second, refers automatic reactions of individual under stressful exam moment. According to Cassady and Johnson (2002), two-dimensional structure of anxiety under worry and emotionality dimensions has been widely embraced since 1970s. Accordingly, whereas emotionality dimension includes dizziness, nausea, panicattack, heart-throb felt under evaluation, worry dimension constituting cognitive dimension of exam anxiety includes internal dialogues about evaluation statuses and cognitive reactions experienced before, during and after the performance. In general, individuals who experience anxiety in the dimension of worry compare their performances with peers, they concern about failure, feel less confident about accomplishing the mission, and they think they will upset their parents or lose their self-worthiness. Spielberger's (1980) exam anxiety scale has been the most common measurement tool for determining these two dimensions.

\section{Purpose of this study}

Although there have been numbers of studies on measuring exam anxiety, almost all of them are directly related with student anxiety (e.g. Liebert \& Morris, 1967; Lowe \& Lee, 2008; Sarason, 1984; Spielberger, 1980; Wren \& Benson, 2004;). On the other hand, no any measurement tool to determine anxiety of parents, one of significant exam anxiety resources of students (Çapulcuoğlu \& Gündüz, 2013; Hill \& Wigfield, 1984) has been found in the relevant literature. Although some studies (Brown-Jacobsen, Wallace, \& Whiteside, 2011; Comer \& Kendall, 2004; Grills \& Ollendick, 2003; Harpell \& Andrews, 2012; Kendal \& Flanery-Schroeder, 1998;) compared anxiety of students on the basis of evaluations of parents and teachers, these studies only provide data regarding consistency of anxiety. In this regard, this study aims to develop a scale to measure anxiety of parents regarding exams taken by their children. 


\section{Method}

\section{Participants}

The first study group of the study is consisted of parents whose children were attending to school from the 4th to 12 th grades. The study group consisted of 299 individuals, 169 were female and 130 were male living in a province in The Black Sea Region in Turkey. The mean age of participants was estimated 42.7. The second study group consisted of parents whose children were attending to school from the fourth grade students to seniour college students. The second study group consisted of 200 individuals, 108 were female, 92 were male living in a province in The Black Sea Region in Turkey. The mean age of participants was estimated at 44.13 .

\section{Instruments}

State - Trait Anxiety Inventory (STAI). STAI was developed to determine state and trait anxiety levels of students by Spielberger et al. (1964). Whereas the STAI was adapted to Turkish and reliability, validity and norm studies were conducted by Öner \& Le Compte (1983) It consists of two separate scales containing twenty items each. State Anxiety Scale measures how individuals feel in general at certain time regardless of certain conditions. Trait Anxiety Scale, independent of current status and condition of the person, measures how a person feels in general. Total score obtained from both scale ranges between 20 and 80 . The higher score indicate the higher state and trait anxiety level for each dimension. Internal consistency and reliability scores of scales were estimated for the State Anxiety Scale at the range of .94 and .96; for the Trait Anxiety Scale at the range of .83 and .87 in different samples (Öner \& Le Compte, 1985). In the current study, Cronbach's Alpha coefficients of state anxiety scale was .76 whereas Trait Anxiety Scale was .82, respectively.

\section{Procedure}

At the first stage, the structure that needs to be measured was described by taking steps necessary for developing a scale into consideration. Then, the scales employed in the relevant literature were reviewed and parents were requested to write an article about exam anxiety. From this point, item pool was created, which consisted of 71 items. Afterwards of evaluation of these items by experts, 21 items were removed from the scale and final draft scale comprised of 50 items was prepared. Parents expressed their agreement levels with the presented items according to the 5-point Likert scale. The reliability and validity study of the scale were 
conducted on two groups. Obtained findings from the first study group were utilized for to determine underlying factor structure of the new scale exploratory factor analysis and reliability of the structure; the second study group was utilized for confirmatory factor analysis and reliability of the measure.

\section{Data Analysis}

In analysis of collected data, the SPSS 21.0 and LISREL 8.8 were utilized. Whereas Explanatory Factor Analysis (EFA) and Confirmatory Factor Analysis (CFA) were used for validity of the scale in the first study group, the Cronbach's Alpha coefficients were estimated for evaluation of reliability of the scale. Before the EFA, the normality of data and adequacy of sampling size were assessed by the Bartlett's Test which suggested that it was significant $(\mathrm{p}<0.01)$ and that the KMO value was sufficient with .934. On the second study group, the validity of the structure was re-evaluated as well as validity of the measure of the state and trait anxiety scales was examined. Moreover, Cronbach's Alpha coefficient was estimated for reliability for the second group as well.

\section{Results}

\section{The First Study}

\section{Construct Validity}

Validity of the Exam Anxiety Scale for Parents (EASP) was evaluated on the basis of EFA and CFA. Whereas the EFA was conducted in the beginning, it was limited with two factors in line with the relevant literature. At the first stage, item-total correlations were examined for the draft scale with 50 items. The four items with item value lower than .40 were removed from the scale. Additionally, items remained outside of dimensions were removed. In the next step, items overlapping in different dimensions were removed from the scale. Finally, items with low item factor loading were removed; in the end the scale was consisted of totally 18 items. Whereas the scale was limited with two dimensions as a result of the analysis, it was comprised of totally 18 items. On the basis of the literature, these factors were referred as worry (1-3-5-7-9-11-13-15-17) and physiological (2-4-6-8-10-12-14-16-18) dimensions (Appendix 1 Turkish version and Appendix 2 English version).

It was determined that whereas the factor loadings of the items from the worry dimension were in the range of .41 and .83 , the ones from the physiological dimension were in the 
range of .68 and .80. For both dimensions, explained total variance was estimated at $55.44 \%$. In terms of each sub-dimension, while worry dimension was able explain variance by $26.08 \%$, physiological dimension was $29.35 \%$. Table 1 shows factor loadings of items and total item correlations which indicate the relationship between the individual item and the whole group of items of the relevant dimension.

Table 1. Factor loading and item-total correlation values of EASP' dimensions

\begin{tabular}{llll}
\hline Item No & $\begin{array}{l}\text { Physiological Dimen- } \\
\text { sion }\end{array}$ & Worry Dimension & $\begin{array}{l}\text { Total Item Correlation } \\
\text { of EASP' Dimensions }\end{array}$ \\
\hline 2 & .72 & & .71 \\
4 & .77 & & .70 \\
6 & .68 & & .62 \\
8 & .71 & & .71 \\
10 & .69 & & .64 \\
12 & .80 & & .73 \\
14 & .78 & & .71 \\
16 & .73 & & .70 \\
18 & .74 & .54 & .66 \\
1 & & .71 & .39 \\
3 & & .76 & .66 \\
5 & & .83 & .72 \\
7 & & .78 & .78 \\
9 & & .73 & .70 \\
11 & & .41 & .69 \\
13 & & .75 & .35 \\
15 & & .63 & .72 \\
17 & & 4.70 & .57 \\
Eigenvalue & & 26.08 & \\
Explained Variance (\%) & 29.35 & & \\
\hline
\end{tabular}

As a result of the EFA, a two-dimensional structure emerged and the CFA was conducted to confirm this structure. At the end of analysis, it was observed that all $t$ values were significant and in the range of 6.05 and 15.77. Whereas Figure 1 shows findings regarding factor loadings of the scale, degree of fit statistics of the CFA conducted for Construct Validity showed in Table 2 . 


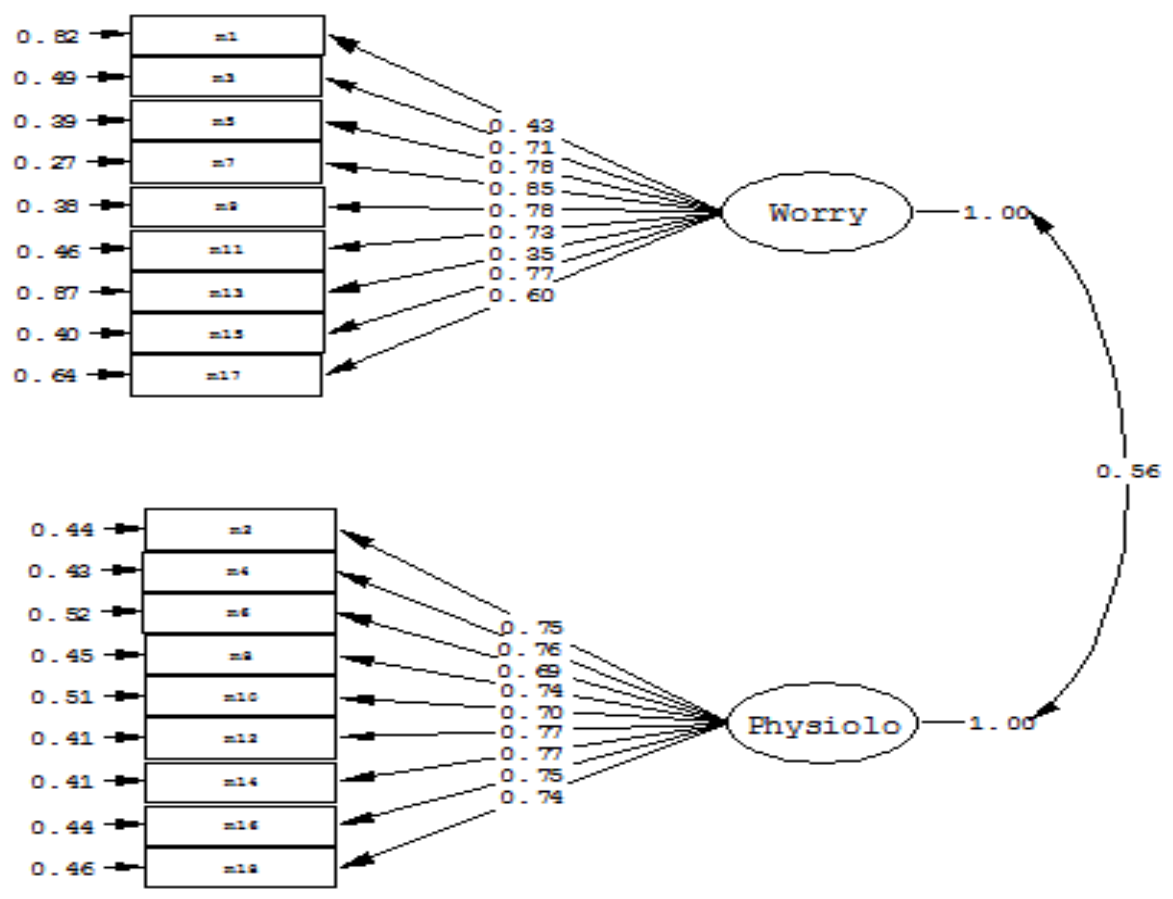

Figure 1. Factor loadings regarding confirmatory factor analysis (CFA)

According to Figure 1, it was observed that factor loading values of the model were ranging for worry dimension between .35 and .85; for physiological dimension between .69 and .77; and that they were sufficient. Model-data fit values were above acceptable levels $\left(\chi^{2} / \mathrm{sd}=\right.$ 2.02, $\mathrm{RMSEA}=.058, \mathrm{SRMR}=.075 \mathrm{CFI}=.98, \mathrm{NFI}=.97, \mathrm{TLI}=.98)$.

\section{Reliability}

The reliability of the scale was examined based on the estimated Cronbach's Alpha coefficients. Accordingly, Cronbach's Alpha value was estimated at .91 for the overall scores; at .88 for worry dimension; and at .91 for physiological dimension.

\section{The Second Study}

\section{Criterion Related Validity}

As the construct validity was determined in the first study, the relationship of the scale with the scales believed to measure similar structure in the second study. For criterion related validity, state and trait anxiety scales were utilized. The relationship of state and trait anxiety 
with exam anxiety has been reported by countless number of studies. The relationships among variables were shown in Table 3.

Table 3. Correlations between PEAS and State-Trait Anxiety Scales

\begin{tabular}{llllll}
\hline & $\mathbf{1}$ & $\mathbf{2}$ & $\mathbf{3}$ & $\mathbf{4}$ & $\mathbf{5}$ \\
\hline 1. Trait Anxiety & & & & & \\
2. State Anxiety & $.63^{*}$ & & & & \\
3. Exam Anxiety Scale for Parents -Worry & $.45^{*}$ & $.30^{*}$ & & & \\
4. Exam Anxiety for Parent-Physiological & $.47^{*}$ & $.40^{*}$ & $.65^{*}$ & & \\
5. Exam Anxiety for Parent-Total & $.51^{*}$ & $.39^{*}$ & $.90^{*}$ & $.91^{*}$ & \\
\hline Note. ${ }^{*} p .01$ & & &
\end{tabular}

As seen in Table 3, there was significant moderate correlation between exam anxiety of parent and state and trait anxiety levels.

\section{Reliability}

In order to evaluate reliability of the PEAS, Cronbach's Alpha values were estimated. Accordingly, the Cronbach's Alpha coefficient was estimated for the total scores at .93; for worry dimension at .88; and for physiological dimension at .91 .

\section{Discussion and Conclusions}

In this study, a scale for measuring the anxiety perceived by parents regarding exams taken by their children was developed. According to the EFA analysis, it was seen that the scale was consisted of a structure with dual dimension. Additionally, the CFA results confirmed the dual structure of the scale. Beside validity of the construct, state and trait anxiety scales and their validities were evaluated. Medium level significant association was determined between exam anxiety of parent and state and trait anxiety scales. Cronbach's Alpha values estimated for reliability of scale in the first and second studies were found to be adequate.

According to the current literature, exam anxiety has various conceptualisms and it has been considered in different dimensions. As it was reported by Cassady and Johnson (2002), there is no consensus on structure of the exam anxiety yet. For instance, Sarason (1984) considered exam anxiety under four dimensions of worry tension test-irrelevant thinking and bodily symptoms. However, it was seen that Wren and Benson (2004) considered exam anxiety 
under three dimensions of thoughts, off- task behaviors and automatic reactions. In another study conducted by Lowe and Lee (2008), exam anxiety was conceptualized under six dimensions. Cassady and Johnson (2002) focused on cognitive dimension of exam anxiety and developed a one-dimensional scale for measuring exam anxiety.

It is reported in the relevant literature that structure of exam anxiety is frequently taken as worry and emotionality (Cassady \& Johnson, 2002); and measurements based on these two dimensions were more common (Stöber, 2004). Furthermore, according to Cassady and Johnson (2002), worry dimension was representing cognitive aspect of the exam anxiety; but this reference was not accurate enough to represent cognitive processes. Moreover, cognitive dimension of the exam anxiety is more closely related with academic performance. When items expressed in dimensions referred as cognitive dimension or thinking by both Cassady \& Johnson (2002) and Wren \& Benson (2004) are considered, it could be seen that there are items such as "thinking about exam results, obsessing with something else, feeling comfortable or concerning about something". In the present study, worry dimension of exam anxiety perceived by parents was structured on the basis of aforesaid studies. Physiological dimension in this study could be considered as the equivalence of the bodily symptoms indicated in the study of Sarason (1984) or automatic reactions dimension indicated by Wren and Benson (2004). Moreover, based on the cultural characteristics and structure of Turkish language, whereas items including cognitive and emotional aspects were considered under worry dimension, automatic reactions accompanied worry such as sweating, and difficulty in breathing were referred as physiological dimension.

This study conducted to measure exam anxiety of parents introduced a measurement tool adequate in terms of psychometric dimension. Yet, it would be beneficent to apply the scale on other sampling groups in order to ensure external validity of EASP. Moreover, it is also reported in the literature that there are significant correlations between exam anxiety and attitudes of parents. Existence and significance of similar relationship with parent exam anxiety could be investigated as well. Finally, determination of extent of the relationship between exam anxieties of parents and exam anxiety $f$ their children would make contribute into comprehension of exam anxiety and thus providing more accurate solutions during guidance services. 
This study conducted to measure exam anxiety of parents introduced a measurement tool adequate in terms of psychometric dimension. Although, two-dimensional structure is found to be the most appropriate factor structure in applied analysis, especially it involving the thoughts in the worry dimension (I care about his/her exam scores) and the reactions caused by these thoughts (I worry about that he/she would make mistakes in exams) indicate that the scale will consist of at least three dimensions. Albeit, a three dimensional structure couldn't be obtained in this study, it would be beneficial to review PETA while constructing factor structure in other sampling groups by inserting new entries. Moreover, it is also reported in the literature that there are significant correlations between exam anxiety and attitudes of parents. Existence and significance of similar relationship with parent exam anxiety could be investigated as well. It is recommended for the future research to investigate what the predictors of parental exam anxiety are, as well as the degree of the relationship between the parental test anxiety and the child's exam anxiety. In addition, parent exam anxiety could also be investigated for different cultures and at different educational levels. Finally, determination of extent of the relationship between exam anxieties of parents and exam anxiety their children would make contribute into comprehension of exam anxiety and thus providing more accurate solutions during guidance services.

Lastly, there were limitations to this study. Parents of children attending different classes from 4th grade to university participated in this study. Parents of students at all levels may not have the same test anxiety. This study was conducted in the Black Sea region in Turkey. Therefore, the findings of this study may not be generalized out side of this geografical area. In different regional areas and cultural backgrounds, parental exam anxiety may or may not be experienced the same way.

\section{Acknowledgments}

This study was presented in abstract form at the international Educational Sciences Congress, 2-4 June, 2016 in Sarajevo / Bosnia and Herzegovina. Moreover, This study was also supported by the project number 15-056 of SEB-BAP within the scope University of Amasya Scientific Research Projects. 


\section{References}

Adams, E. B., \& Sarason, I. G. (1963). Relation between anxiety in children and their parents. Child Development, 34 (1), 237-246. doi: 10.1111/j.1467- 8624.1963.tb05135.x

Alisinanoğlu, F., \& Ulutaş, İ. (2003). Çocukların kaygı düzeyleri ile annelerinin kaygı düzeyleri arasındaki ilişkinin incelenmesi. Eğitim ve Bilim, 28(128), 65-71.

Bacanlı, F., \& Sürücü, M. (2006). ilköğretim 8. sınıf öğrencilerinin sınav kaygıları ve karar verme stilleri arasındaki ilişkilerin incelenmesi. Kuram ve Uygulamada Ĕgitim Yönetimi Dergisi, 12(1), 7-35.

Başal, H. A. (1997). Denetim odağı ile sınav kaygısı arasındaki ilişki. Eğitim ve Bilim, 2l(103), 4-11.

Brown-Jacobsen, A. M., Wallace, D. P., \& Whiteside, S. P. H. (2010). Multimethod, multiinformant agreement, and positive predictive value in the identification of child anxiety disorders using the SCAS and ADIS-C. Assessment, 18, 382-392. doi: $10.1177 / 1073191110375792$

Burger, J.M. (2006). Kişilik (Çev.: D. Sarıoğlu). İstanbul: Kaknüs Yayınları.

Cassady, J. C., \& Johnson, R. E. (2002). Cognitive test anxiety and academic performance. Contemporary Educational Psychology, 27(2), 270-295. doi: 10.1006/ceps.2001.1094

Comer, J. S., \& Kendall, P. C. (2004). A symptom-level examination of parent-child agreement in the diagnosis of anxious youths. Journal of the American Academy of Child \& Adolescent Psychiatry, 43, 878- $886 . \quad$ doi: 10.1097/01.chi.0000125092.35109.c5

Çakmak, Ö., \& Hevedanlı, M. (2005). Eğitim ve fen-edebiyat fakülteleri biyoloji bölümü öğrencilerinin kaygı düzeylerinin çeşitli değişkenler açısından incelenmesi. Elektronik Sosyal Bilimler Dergisi, 14(14), 115-127.

Çapulcuoğlu, U., \& Gündüz, B. (2013). Öğrenci tükenmişliğini yordamada stresle başaçıkma, sınav kaygısı, akademik yetkinlik ve anne-baba tutumları değişkenlerinin incelenmesi. Eğitim Bilimleri Araştırma Dergisi, 3(1), 201-218.

Duman, G. K. (2008). İlköğretim 8. sınıf öğrencilerinin durumluk sürekli kaygı düzeyleri ile sınav kaygısı düzeyleri ve ana-baba tutumları arasındaki ilişkinin incelenmesi. Yüksek Lisans Tezi, Dokuz Eylül Üniversitesi Eğitim Bilimleri Enstitüsü, İzmir.

Ergene, T. (2003). Effective interventions on test anxiety reduction: A meta-analysis. School Psychology International, 24(3), 313-328. doi: 10.1177/01430343030243004

Ergene, T. (2011). Lise öğrencilerinin sınav kaygısı, çalışma alışkanlıkları, başarı güdüsü ve 
akademik performans düzeyleri arasındaki ilişkilerin incelenmesi. Eğitim ve Bilim, 36(160), 320-330.

Eum, K., \& Rice, K. G. (2011). Test anxiety, perfectionism, goal orientation, and academic performance. Anxiety, Stress, \& Coping, 24(2), 167-178. doi: $10.1080 / 10615806.2010 .488723$

Fincham, F. D., Hokoda, A., \& Sanders Jr, R. (1989). Learned helplessness, test anxiety, and academic achievement: A longitudinal analysis. Child Development, 60 (1), 138-145. doi: $10.2307 / 1131079$

Gençdoğan, B. (2006). Lise öğrencilerinin sınav kaygısı ile boyuneğicilik düzeyleri ve sosyal destek algısı arasındaki ilişkiler. Atatürk Üniversitesi Sosyal Bilimler Enstitüsü Dergisi, $7(1), 153-164$.

Güler, D., \& Çakır, G. (2013). Lise son sınıf öğrencilerinin sınav kaygısını yordayan değişkenlerin incelenmesi. Türk Psikolojik Danışma ve Rehberlik Dergisi, 4(39), 82-94.

Hanımoğlu, E. \& İnanç, B. Y. (2011). Seviye belirleme sınavına girecek olan ilköğretim ikinci kademe öğrencilerinde sınav kaygısı mükemmeliyetçilik ve anne baba tutumu arasındaki ilişkinin incelenmesi. Çukurova Üniversitesi Sosyal Bilimler Enstitüsü Dergisi, 20(1). 351-366.

Harpell, J. V., \& Andrews, J. J. (2012). Multi-informant test anxiety assessment of adolescents. Psychology, 3(07), 518-524. doi: 10.4236/psych.2012.37075

Hill, K. T., \& Wigfield, A. (1984). Test anxiety: A major educational problem and what can be done about it. The Elementary School Journal, 85(1), 105-126. doi: 10.1086/461395

Hong, E. (1998). Differential stability of individual differences in state and trait anxiety. Learning and Individual Differences, 10 (1), 51- 69. doi: 10.1016/S10416080(99)80142-3

Grills, A. E., \& Ollendick, T. H. (2003). Multiple informant agreement and the anxiety disorders interview schedule for parents and children. Journal of the American Academy of Child \& Adolescent Psychiatry, 42, 30-40. doi: 10.1097/00004583-200301000-00008

Kendall, P. C., \& Flannery-Schroeder, E. (1998). Methodological issues in treatment research for anxiety disorders in youth. Journal of the American Academy of Child and Adolescent Psychiatry, 40, 787-794. doi: 10.1023/A:1022630706189

Koçkar, A. İ., Kılıç, B. G., \& Şener, Ş. (2002). İlköğretim öğrencilerinde sınav kaygısı ve akademik başarı. Çocuk ve Gençlik Ruh Să̆lı̆̆ Dergisi, 9(2), 100-105.

Koruklu, N., Öner, H., \& Oktaylar, H. C. (2006). Sınav kaygısı ile başa çıkma programının sınav kaygısına etkisine yönelik deneysel bir çalışma. Dokuz Eylül 
Üniversitesi Buca Eğitim Fakültesi Dergisi, 19, 5-11.

Liebert, R. M., \& Morris, L. W. (1967). Cognitive and emotional components of test anxiety: A distinction and some initial data. Psychological Reports, 20(3), 975-978. doi: 10.2466/pr0.1967.20.3.975

Lowe, P. A., \& Lee, S. W. (2008). Factor structure of the Test Anxiety Inventory for Children and Adolescents (TAICA) scores across gender among students in elementary and secondary school settings. Journal of Psychoeducational Assessment, 26(3), 231-246. doi: $10.1177 / 0734282907303773$

McDonald, A. S. (2001). The prevalence and effects of test anxiety in school children. Educational Psychology, 21(1), 89-101. doi: 10.1080/01443410020019867

TMNE (2016). Ölçme, Değerlendirme ve Sınav Hizmetleri Genel Müdürlüğü Veri Analizi, İzleme ve Değerlendirme Daire Başkanlığı. retrieved from http://odsgm.meb.gov.tr/test/analizler/docs/2015-

2016OrtakSinavlar2.DonemSayisalBilgiler.pdf

Morris, L. W., \& Liebert, R. M. (1970). Relationship of cognitive and emotional components of test anxiety to physiological arousal and academic performance. Journal of consulting and clinical psychology, 35(3), 332-337. doi: 10.1037/h0030132

Öner, N. (1990). Sınav kaygısı envanteri el kitabı. İstanbul: Yöret Yayınları.

Öner, N., \& Le Compte, A. (1998). Süreksiz durumluk sürekli kaygı envanteri el kitabı. İstanbul: Boğaziçi Üniversitesi Yayınları.

SSPC (2016a). 2016-YGS sayısal bilgiler. retrieved from: http://dokuman.osym.gov.tr/pdfdokuman/2016/YGS/2016_YGS_Sayisal_Bilgiler.pdf

SSPC (2016b). KPSS: kamu personel seçme sinavi. retrieved from http://www.osym.gov.tr/TR,10258/2016.html

Park, J. H., \& Park, J. M. (2010). The effects of children's ego-resilience and social support on exam anxiety and school adjustment. Korean Journal of Child Studies, 31(6), 125-134.

Peleg-Popko, O. (2002). Children's test anxiety and family interaction patterns. Anxiety, Stres and Coping, 15(1), 45-59. doi: 10.1080/10615800290007281

Sanz de acedo, M. T., \& Sanz de acedo, M. L. (2012). Relationships between state and trait anxiety with verbal and graphic creativity in students in compulsory secondary education. Electronic Journal of Research in Educational Psychology, 10(3), 11231138.

Sarason, I. G. (1984). Stress, anxiety, and cognitive interference: reactions to tests. Journal of personality and social psychology, 46(4), 929-938. doi: 10.1037/0022-3514.46.4.929 
Seipp, B., \& Schwarzer, C. (1996). Cross-cultural anxiety research. A review. In C. Schwarzer \& M. Zeidner (Eds.), Stress, anxiety, and coping in academic settings (pp. 13-68). Tubingen: Francke-Verlag.

Spielberger, C. D. (1980). Test anxiety inventory: Preliminary professional manual. Palo Alto, CA: Consulting Psychologists Press.

Steinmayr R, Crede J, McElvany N and Wirthwein L (2016) Subjective Well-Being, Test Anxiety, Academic Achievement: Testing for Reciprocal Effects. Front. Psychol. 6, 113. doi: 10.3389/fpsyg.2015.01994.

Stöber, J. (2004). Dimensions of test anxiety: Relations to ways of coping with pre-exam anxiety and uncertainty. Anxiety, Stress \& Coping, 17(3), 213-226. doi: $10.1080 / 10615800412331292615$

Şahin, H., Günay, T., \& Batı, H. (2006). İzmir ili Bornova ilçesi lise son sınıf öğrencilerinde üniversiteye giriş sınavı kaygısı. Sted, 15(6), 107-113.

Von Der Embse, N., Barterian, J., \& Segool, N. (2013). Test anxiety interventions for children and adolescents: A systematic review of treatment studies from 2000-2010. Psychology in the Schools, 50(1), 57-71. doi: 10.1002/pits.21660

Yıldırım, İ., Gençtanırım, D., Yalçın, İ., \& Baydan, Y. (2008). Sınav kaygısının yordayıcıları olarak akademik başarı, mükemmelliyetçilik ve sosyal destek. Hacettepe Üniversitesi Ĕ̈itim Fakültesi Dergisi, 34, 287-96.

Whaley, S. E., Pinto, A., \& Sigman, M. (1999). Characterizing interactions between anxious mothers and their children. Journal of consulting and clinical psychology, 67(6), 826836. doi: 10.1037/0022-006X.67.6.826

Wigfield, A., \& Eccles, J. S. (1989). Test anxiety in elementary and secondary school students. Educational Psychologist, 24(2), 159-183. doi: 10.1207/s15326985ep2402_3

Wren, D. G., \& Benson, J. (2004). Measuring test anxiety in children: Scale development and internal construct validation. Anxiety, Stress \& Coping, 17(3), 227-240. doi: $10.1080 / 10615800412331292606$ 


\section{Appendix 1. Ebeveyn Sınav Kaygısı Ölçeği}

Sayın Veli; Bu ölçek çocuğunuzun gireceği sınavlara ilişkin sizin görüşünüzü belirlemek amacıyla hazırlanmıştır. Doğru ya da yanlış cevap diye bir şey yoktur. Bu yüzden insanların genelinin düşündügüünden ziyade sizin için en doğru olan cevabı işaretleyin. İşaretlerken rakamların üzerine çarpı (X) işareti koyabilirsiniz. Sizden istenen her bir ifadeyi dikkatli bir şekilde okuyup sizin için ne kadar uygun olduğunu aşağıdaki 5'li derecelendirmeyi kullanarak yapmanızdır. Lütfen boş ifade bırakmayınız. İçten ve samimi yanıtlarınız için teşekkür ederiz.

Hiç katılmıyorum Orta düzeyde katılıyorum

Tamamen Kat1lyorum

1

2

3

4

5

\begin{tabular}{|l|l|l|l|l|l|l|}
\hline \multicolumn{2}{|l}{ Çocuğumun; } & 1 & 2 & 3 & 4 & 5 \\
\hline 1 & sinavlardan aldığı sonuçları önemserim. & 1 & 2 & 3 & 4 & 5 \\
\hline 2 & sınavları olduğu günlerde nabzım yükselir. & 1 & 2 & 3 & 4 & 5 \\
\hline 3 & sınavlarda dikkati dağılır diye endişelenirim. & 1 & 2 & 3 & 4 & 5 \\
\hline 4 & sinavları olduğu günlerde nefesim daralır. & 1 & 2 & 3 & 4 & 5 \\
\hline 5 & sinavlarında hata yapacağından endişelenirim. & 1 & 2 & 3 & 4 & 5 \\
\hline 6 & sinavları olacağı zamanlarda bitkin hissederim. & 1 & 2 & 3 & 4 & 5 \\
\hline 7 & sinavlarda bildiklerini unutmasından endişe duyarım. & 1 & 2 & 3 & 4 & 5 \\
\hline 8 & sinava girdiği zamanlarda kalbim daha hızlı çarpar. & 1 & 2 & 3 & 4 & 5 \\
\hline 9 & sinavlarda bildiklerini yapamamasından kaygılanırım. & 1 & 2 & 3 & 4 & 5 \\
\hline 10 & bazı sınavlarını o kadar dert ederim ki midem bulanır. & 1 & 2 & 3 & 4 & 5 \\
\hline 11 & sinavlarında süreyi yetiştirememesinden endişe duyarım. & 1 & 2 & 3 & 4 & 5 \\
\hline 12 & sinavlara girdiği zamanlarda yüzümde yanma hissederim. & 1 & 2 & 3 & 4 & 5 \\
\hline 13 & geleceğinin sınavlardaki başarısına bağlı olduğunu düşünürüm. & 1 & 2 & 3 & 4 & 5 \\
\hline 14 & sinavlara gireceği dönemlerde uyumakta güçlük çekerim. & 1 & 2 & 3 & 4 & 5 \\
\hline 15 & sınavlarda bildiklerini karıştıracağı düşüncesi beni rahatsız eder. & 1 & 2 & 3 & 4 & 5 \\
\hline 16 & sinavları olduğu zamanlarda vücudumun gerildiğini hissederim. & 1 & 2 & 3 & 4 & 5 \\
\hline 17 & sinavları kötü geçerse emekleri boşa gidecek diye endişelenirim. & 1 & 2 & 3 & 4 & 5 \\
\hline 18 & bazı sınavları olacağı günlerde karnıma ağnlar/kramplar girer. & & & 5 \\
\hline
\end{tabular}




\section{Appendix 2. Exam Anxiety Scale for Parents**}

Dear parents; This scale is prepared to determine your opinion about the exams that will be taken by your child. There is no correct or wrong answer. Thus, please mark the answer option which suits best to your opinion rather than what is thought by people in general. Please mark $(X)$ on the number. Please read each expression carefully and use the 5-point scale below to exhibit how suitable in terms of reflecting your opinion. Please do not leave any expression without an answer. Thank you for sincere and honest answers.

Strongly disagree

Neither agree nor disagree

Strongly agree

\begin{tabular}{|c|c|c|c|c|c|c|c|c|c|}
\hline & 1 & 2 & 3 & 4 & \multicolumn{3}{|c|}{5} & & \\
\hline \multicolumn{10}{|c|}{ Regarding my child, } \\
\hline 1 & \multicolumn{4}{|c|}{ I care about his/her exam scores. } & 1 & 2 & 3 & 4 & 5 \\
\hline 2 & \multicolumn{4}{|c|}{ My pulse increases on the exam days. } & 1 & 2 & 3 & 4 & 5 \\
\hline 3 & \multicolumn{4}{|c|}{ I concern about his/her distraction during exams. } & 1 & 2 & 3 & 4 & 5 \\
\hline 4 & \multicolumn{4}{|c|}{ I am short of breath on his/her exam days. } & 1 & 2 & 3 & 4 & 5 \\
\hline 5 & \multicolumn{4}{|c|}{ I am worry about that he/she would mistake in exams. } & 1 & 2 & 3 & 4 & 5 \\
\hline 6 & \multicolumn{4}{|c|}{ I feel fatigue on the days when he/she has exams. } & 1 & 2 & 3 & 4 & 5 \\
\hline 7 & \multicolumn{4}{|c|}{ I worry about that he/she would forget what already know. } & 1 & 2 & 3 & 4 & 5 \\
\hline 8 & \multicolumn{4}{|c|}{ My heart beat faster when she/she takes an exam. } & 1 & 2 & 3 & 4 & 5 \\
\hline 9 & \multicolumn{4}{|c|}{ I concern about he/she makes mistake about what already knows. } & 1 & 2 & 3 & 4 & 5 \\
\hline 10 & \multicolumn{4}{|c|}{ I am so worried about his/her exams that I feel nauseous. } & 1 & 2 & 3 & 4 & 5 \\
\hline 11 & \multicolumn{4}{|c|}{ I am worried about his/her time will be short for the entire exam. } & 1 & 2 & 3 & 4 & 5 \\
\hline 12 & \multicolumn{4}{|c|}{ I feel rush on my face when he/she is in the exam. } & 1 & 2 & 3 & 4 & 5 \\
\hline 13 & \multicolumn{4}{|c|}{ I believe that his/her future depends his/her success in exams. } & 1 & 2 & 3 & 4 & 5 \\
\hline 14 & \multicolumn{4}{|c|}{ I lose sleep when he/she take exams. } & 1 & 2 & 3 & 4 & 5 \\
\hline 15 & \multicolumn{4}{|c|}{$\begin{array}{l}\text { I feel uncomfortable about that he/she would confused about what al- } \\
\text { ready know. }\end{array}$} & 1 & 2 & 3 & 4 & 5 \\
\hline 16 & \multicolumn{4}{|c|}{ I get stressed when he/she has exam. } & 1 & 2 & 3 & 4 & 5 \\
\hline 17 & \multicolumn{4}{|c|}{$\begin{array}{l}\text { I am worried about his/her failure in exam in case his/her efforts would } \\
\text { be wasted. }\end{array}$} & 1 & 2 & 3 & 4 & 5 \\
\hline 18 & \multicolumn{4}{|c|}{ I feel stomach pain and cramps when he/she has exam. } & 1 & 2 & 3 & 4 & 5 \\
\hline
\end{tabular}

** No analysis has been done for the English version of the Exam Anxiety Scale for Parents. It is put here to solely inform the reader. 